\title{
Modifikasi Pakan Larva Black Soldier Fly (Hermetia illucens) sebagai Upaya Percepatan Reduksi Sampah Buah dan Sayuran
}

\section{Modification of Black Soldier Fly (Hermetia illucens) Larvae Feed as Effort to Accelerate Reduction of Fruits and Vegetables Waste Reduction}

\author{
DANNY YUSUFIANA ROFI", SHINFI WAZNA AUVARIA, SULISTIYA NENGSE, SARITA OKTORINA, \\ YUSRIANTI
}

\begin{abstract}
Program Studi Teknik Lingkungan, Fakultas Sains dan Teknologi, UIN Sunan Ampel, Surabaya
\end{abstract} Email: dannyyusuf2009@gmail.com

\begin{abstract}
Black Soldier Fly (BSF) larvae treatment is one of the organic waste processing alternatives considered to have a faster process than the other organic waste processes. However, in solid organic waste processing, BSF larvae ability to reduce organic waste is relatively low. This research aims to know the optimum waste reduction index of fruit and vegetable waste with the feed modification of fruits and vegetables' waste, analyze the Efficiency of Conversion of Digested food of BSF larvae, and know the survival rate of BSF larvae. This research used an experimental method with four reactors containing 200 larvae on each reactor. Larvae used in this research were aged 7-18 days. A different larva is fed to each reactor with rate of $100 \mathrm{mg} / \mathrm{larva}$ per day. The feed are vegetables, steamed vegetables, fruit, and fermented fruit. The frequency of feeding was once a day, and weight reduction from the treatment was measured daily. Reduction results in the vegetable waste, steamed vegetables, fruit, fermented fruit were $45.29 \%, 42.92 \%, 33.75 \%$, and $46.25 \%$, respectively. According to the results, the reduction of fruits and vegetables' waste using optimum BSF larvae reached $46.25 \%$ in fermented fruit feed treatment.
\end{abstract}

Keywords: BSF larvae, reduction, organic waste, fruit waste, modification

\begin{abstract}
ABSTRAK
Larva Black Soldier Fly (BSF) merupakan salah satu alternatif pengolahan sampah organik yang dinilai lebih cepat daripada pengolah sampah organik lainnya. Namun dalam pengolahan sampah organik yang padat, kemampuan larva BSF dalam mereduksi sampah organik cukup rendah. Penelitian ini bertujuan untuk mengetahui reduksi optimum sampah organik buah dan sayuran dengan modifikasi komposisi umpan sampah buah dan sayuran, untuk menganalisis konversi pakan yang dapat dicerna larva BSF, dan mengetahui tingkat keberhasilan hidup larva BSF. Penelitian ini menggunakan metode eksperimental menggunakan empat reaktor yang berisi 200 ekor larva pada setiap reaktornya. Larva yang digunakan dalam penelitian ini berumur 7-18 hari. Setiap reaktor diberikan umpan larva yang berbeda dengan laju pengumpanan $100 \mathrm{mg} / \mathrm{larva}$ per hari. Umpan tersebut, di antaranya sayuran, sayuran dikukus, buah, dan buah difermentasi. Frekuensi pemberian umpan dilakukan satu hari sekali dan pengurangan berat umpan dari perlakukan yang diberikan diukur setiap hari. Hasil reduksi pada sampah sayuran, sayuran dikukus, buah, buah difermentasi masing-masing: 45,29\%, 42,92\%, 33,75\%, dan 46,25\%. Berdasarkan hasil tersebut, reduksi sampah organik buah dan sayuran dengan larva BSF optimum, mencapai $46,25 \%$ pada perlakuan umpan buah fermentasi.
\end{abstract}

Kata kunci: larva BSF, sampah organik, sampah buah, sampah sayuran, modifikasi

\section{PENDAHULUAN}

\subsection{Latar Belakang}

Persampahan merupakan permasalahan yang kompleks dihadapi semua negara. Indonesia memiliki laju pertumbuhan penduduk desa dan kota Tahun 2015 hingga 2020, sebesar $1,19 \%$. Sedangkan laju timbulan sampah sebesar $1 \%$ pertahun ${ }^{(1)}$. Timbulan sampah perhari di Indonesia, mencapai 175.000 ton ${ }^{(2)}$ Setiap rumah tangga rata-rata menghasilkan 2,5 kg dengan persentase sampah organik mencapai $44,5 \%{ }^{(3)}$. Persentase pengelolaan sampah dilakukan di Indonesia ditimbun di TPA $69 \%$, sisanya dibakar 5\%, didaur ulang dan dikompos $7 \%$, dikubur $10 \%$, dan tidak terkelola 7\%. Sementara pengolahan sampah di TPA, 90\% masih dengan cara open dumping ${ }^{(2)}$. 
Sejak diterbitkannya UU No. 18 Tahun 2008 menunjukkan progres pengelolaan sampah di Indonesia semakin intensif. Terbukti di beberapa kota maupun kabupaten telah menggunakan konsep 3R (Reduce, Reuse, Recycle). Bentuk $3 R$ yang dilakukan, mulai dari reduksi di sumber dengan pembuatan bank sampah, komposting skala rumah tangga dan komunal di tingkat gang atau RT, dan pengolahan di TPS. Pengolahan sampah organik di TPS dapat dilakukan di TPS 3R maupun TPST.

Pengolahan sampah organik di sumber, pada umumnya menggunakan metode komposting. Namun proses komposting membutuhkan waktu yang cukup lama dalam pendegradasian sampah organik. Larva Black Soldier Fly (BSF) merupakan metode pengolah alternatif yang mempunyai percepatan reduksi mencapai $62,68-73,98 \%{ }^{(4)}$. Nilai percepatan reduksi bervariatif disebabkan oleh perbedaan karakteristik sampah yang diberikan pada larva BSF. Sampah organik yang memiliki karakteristik keras, lebih sukar proses reduksinya.

Pemanfaatan larva BSF dapat dinilai dari reduksi sampah organik yang dapat dilihat dari persentase reduksi sampahnya. Larva BSF dapat lebih cepat mereduksi sampah organik yang bertekstur lunak seperti sisa makanan, sayur, buah, dan sampah organik terfermentasi ${ }^{(5)}$. Oleh karena itu, dilakukan upaya percepatan pengolahan/reduksi sampah

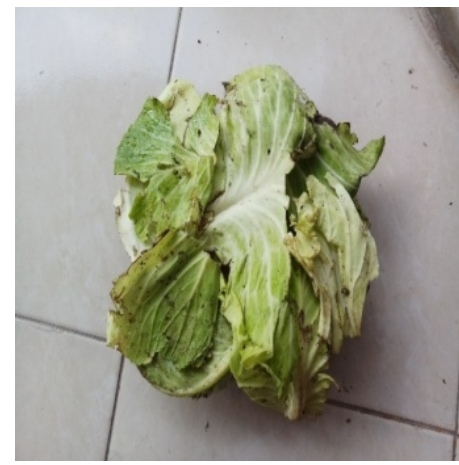

Gambar 1. Sayuran

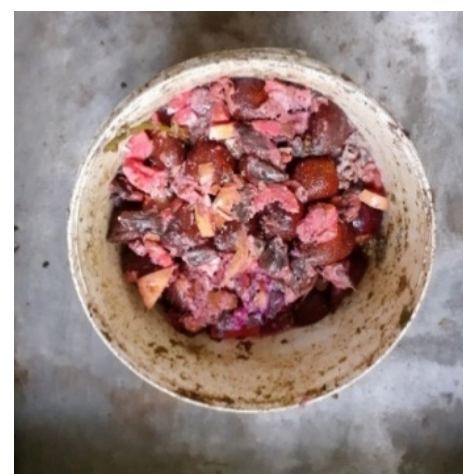

Gambar 3. Buah fermentasi organik dengan melakukan modifikasi pakan dari jenis sampah tersebut untuk larva BSF. Diperlukan sebuah penelitian untuk menganalisis modifikasi pakan larva BSF optimum dalam reduksi sampah organik, terutama sampah buah dan sayur.

\subsection{Tujuan Penelitian}

Tujuan dari penelitian ini adalah untuk mengetahui persentase reduksi sampah atau waste reduction indeks dari umpan sayuran, sayuran dikukus, buah, dan buah difermentasi. selanjutnya mengetahui konversi pakan yang dapat dicerna atau efficiency of conversion of digested food oleh larva BSF dari umpan sayuran, sayuran dikukus, buah, dan buah difermentasi, dan berapa tingkat keberhasilan hidup atau survival rate dari umpan sayuran, sayuran dikukus, buah, dan buah difermentasi.

\section{BAHAN DAN METODE}

Penelitian ini bertujuan untuk mengetahui percepatan reduksi sampah organik, konversi sampah organik yang dapat dicerna, dan tingkat keberhasilan hidup larva BSF. Dalam penelitian ini terdapat 4 reaktor 2 pengulangan dengan pemberian umpan berbeda, di antaranya: sayuran, sayuran dikukus, buah, dan buah difermentasi. Jenis umpan pakan BSF yang diberikan, disajikan pada Gambar 1 sampai 4.

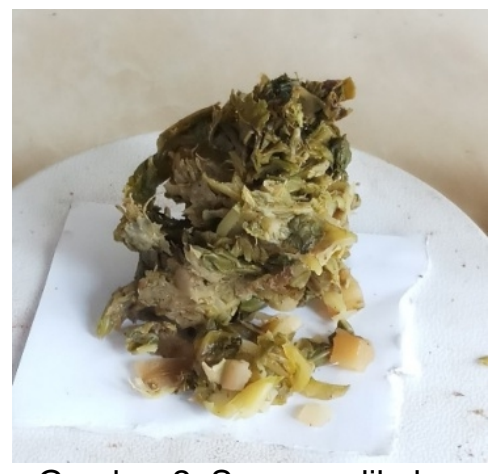

Gambar 2. Sayuran dikukus

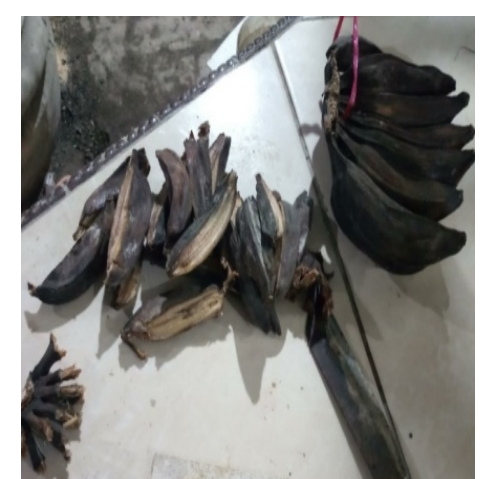

Gambar 4. Buah 
Setiap reaktor membutuhkan 200 ekor larva dengan laju pengumpanan 100 mg/larva/hari. Pengolahan data dalam penelitian ini menggunakan metode deskriptif kuantitatif dengan rumus sebagai berikut:

\section{a. Waste Reduction Indeks (WRI) ${ }^{(6)}$ :}

$D=\frac{W-R}{W}$.

$W R I=\frac{D}{t} X 100$

Keterangan:

$\mathrm{D} \quad=$ Penurunan pakan total $(\mathrm{g})$

$\mathrm{W}$ = Jumlah pakan total $(\mathrm{g})$

$\mathrm{R} \quad=$ Sisa pakan total setelah waktu tertentu $(\mathrm{g})$

$\mathrm{WRI}=$ Indeks pengurangan limbah (Waste Reduction Index) $(\% /$ hari $)$

$\mathrm{t} \quad=$ Total waktu larva memakan pakan (hari)

\section{b. Efficiency of Conversion of Digested food} $(E C D)^{(7)}$ :

$E C D=\frac{B}{(I-F)} X 100 \%$

Keterangan:

$E C D=$ Efisiensi konsumsi sampah organik yang dapat dicerna (\%)

$\mathrm{B}=$ Pertambahan bobot larva selama masa periode makan larva $(\mathrm{mg})$, didapatkan dari pengurangan bobot akhir dikurangi bobot awal larva (mg)
= Jumlah pakan sampah organik yang dikonsumsi, didapatkan dari pengurangan berat pakan sampah organik awal dikurangi berat akhir (mg)

= Berat sisa sampah pakan sampah organik dan hasi ekskresi (mg)

\section{Survival Rate ${ }^{(8)}$ :}

$S R=\frac{y}{\mathrm{z}} X \mathbf{1 0 0} \%$

Keterangan:

$\mathrm{SR}=$ Survival rate $(\%)$

$\mathrm{y} \quad=$ Jumlah total larva yang hidup di akhir pemeliharaan (larva)

$\mathrm{z} \quad=$ Jumlah total larva yang hidup di awal pemeliharaan (larva)

\section{HASIL DAN PEMBAHASAN}

\subsection{Pertumbuhan Larva BSF}

Pertumbuhan Black Soldier Fly (BSF) terdapat 5 fase, di antaranya: fase telur, fase larva, fase prepupa, fase pupa, dan fase lalat dewasa. Setiap fase memiliki perlakuan dan umur yang berbeda. Perbedaan perlakuan setiap fase dapat dilihat pada Tabel 1. Pada penelitian ini, rata-rata umur total siklus BSF 41 hari. Rincian umur BSF dapat dilihat pada Gambar 5. Lamanya siklus BSF bergantung pada 3 faktor, di antaranya: kualitas dan kuantitas sumber makanan, kondisi hidup, dan lingkungan (suhu dan intensitas cahaya).

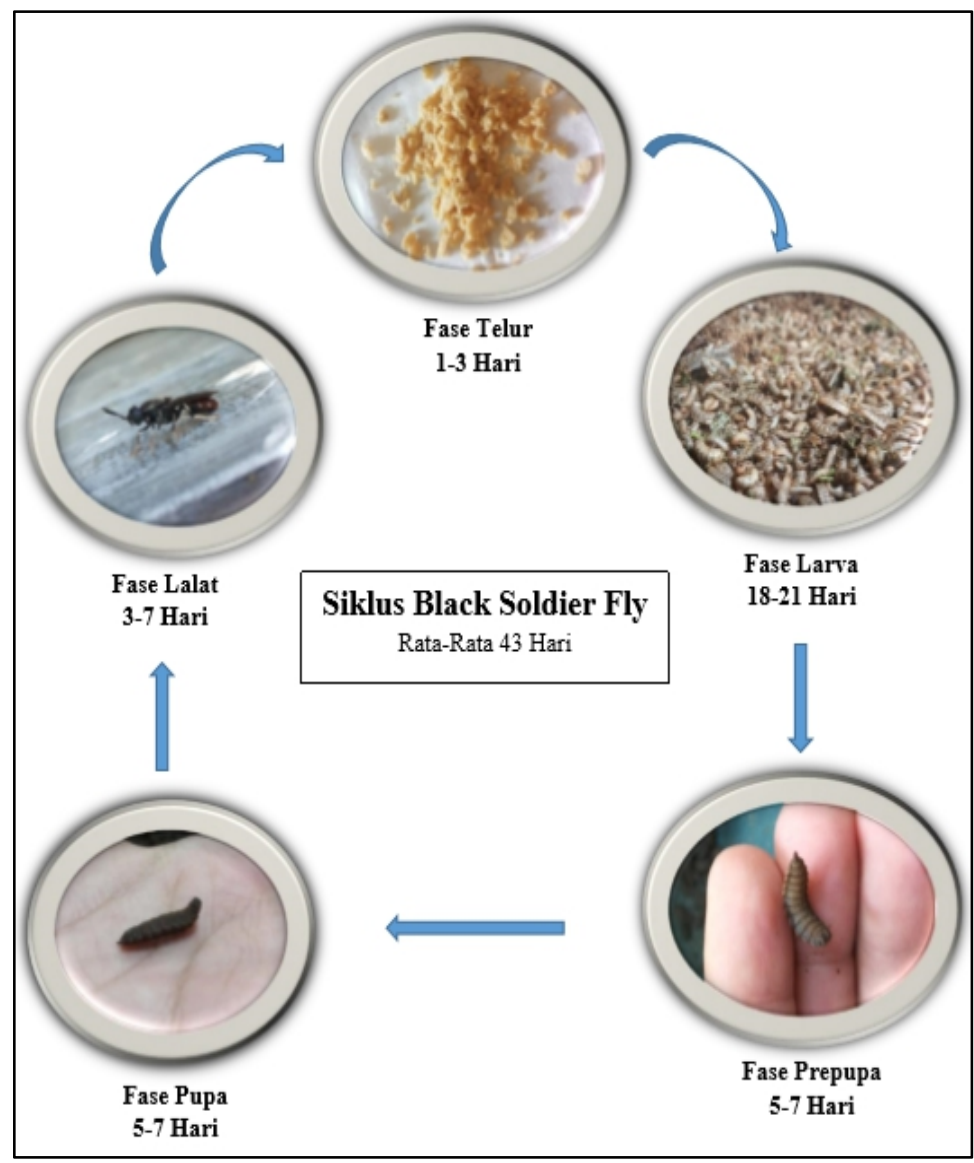

Gambar 5. Siklus hidup BSF 
Tabel 1. Perlakuan fase BSF

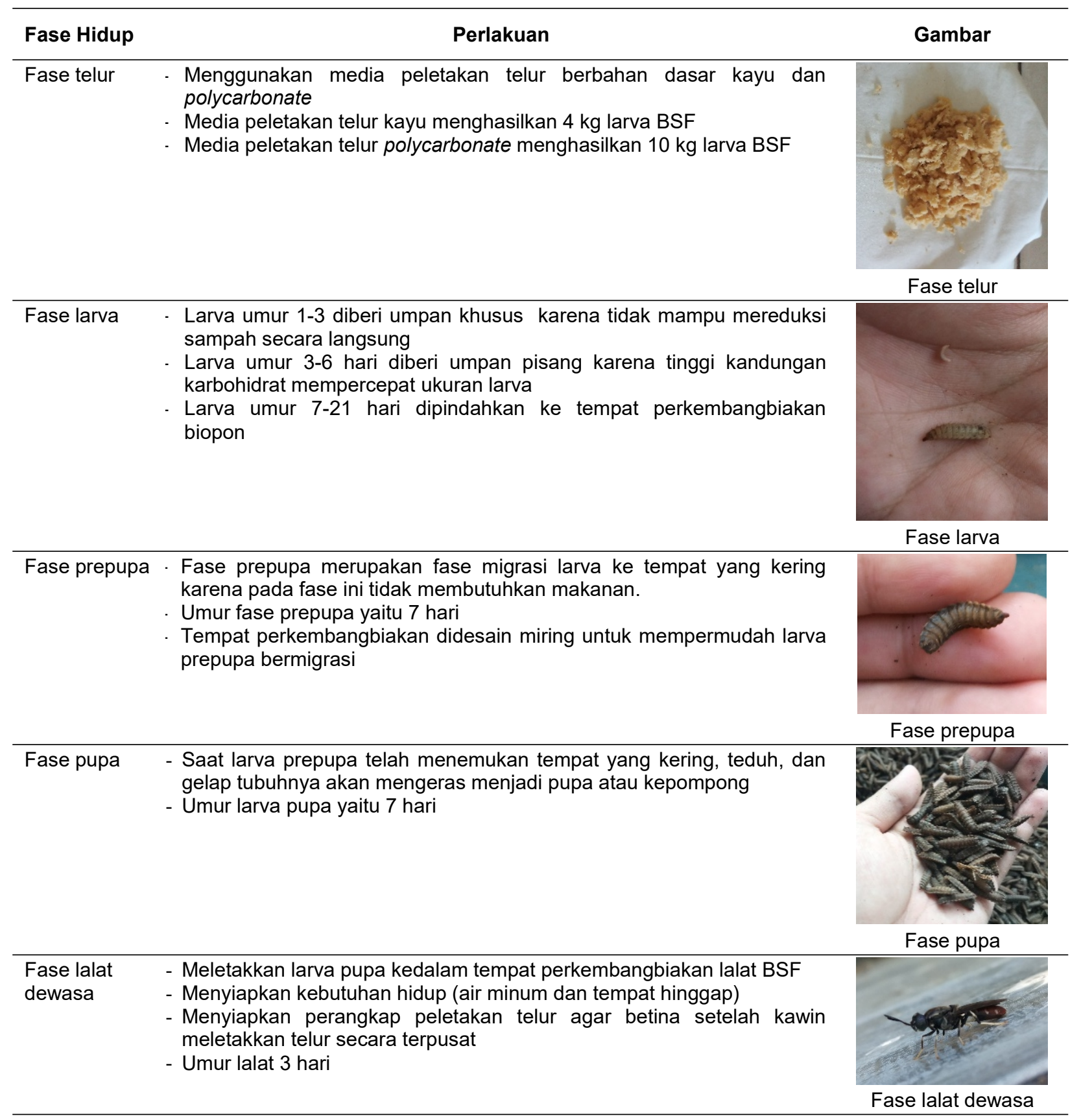

\subsection{Waste Reduction Index}

Pengolahan sampah organik dengan memanfaatkan Larva BSF menjadi salah satu teknologi terbarukan dengan nilai ekonomi yang tinggi dibandingkan dengan teknologi pengolahan sampah organik lain. Berdasarkan hasil penelitian, perbandingan reduksi sampah organik menggunakan larva BSF dengan serangga lain, menunjukkan bahwa larva BSF memiliki percepatan reduksi paling baik ${ }^{(9)}$. Reduksi sampah organik dapat diukur dari perbedaan berat awal sampah dan berat akhir yang telah diberikan kepada larva BSF dalam setiap reaktornya. Pertumbuhan panjang dan berat larva BSF akan mencerminkan tingkat reduksi sampah organiknya. Namun terdapat faktor lain penentu nilai reduksi sampah organik yaitu tingkat kematian, keadaan lingkungan, dan jenis umpan yang diberikan kepada larva BSF. Larva BSF cenderung akan mengkonsumsi umpan yang mereka sukai terlebih dahulu, artinya jika terdapat 2 atau lebih jenis sampah yang berbeda dalam satu tempat perkembangbiakannya larva BSF akan mengkonsumsi umpan yang lunak, rendah serat dan bernutrisi terlebih dahulu. Sehingga menyebabkan perbedaan bobot dan panjang antara larva satu dengan lainnya. 


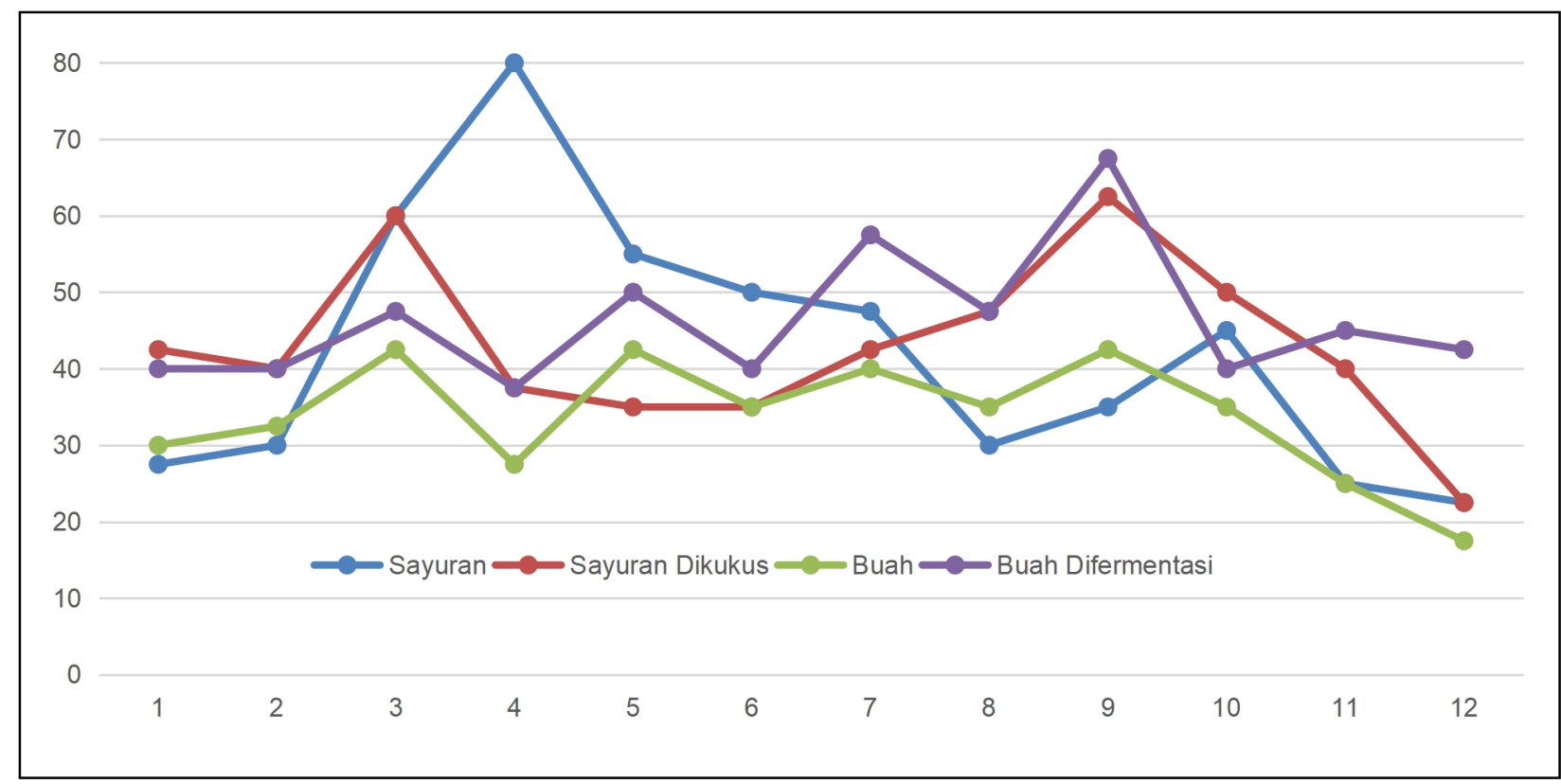

Gambar 6.Persentase reduksi sampah organik larva BSF

Tabel 2. Nilai Waste Reduction Index

\begin{tabular}{lcccc}
\hline Pengulangan & Sayuran (\%) & Sayuran dikukus (\%) & Buah (\%) & Buah difermentasi (\%) \\
\hline Pengulangan 1 & 41,25 & 42,92 & 32,92 & 46,67 \\
Pengulangan 2 & 43,33 & 42,92 & 34,58 & 45,83 \\
Rata - Rata & 42,29 & 42,92 & 33,75 & 46,25 \\
\hline
\end{tabular}

Waste Reduction Indeks (WRI) merupakan perhitungan untuk mengetahui kemampuan larva BSF mengkonsumsi umpan dalam waktu yang ditentukan. Nilai WRI mencerminkan palatabilitas atau kesukaan larva BSF memilih makanannya. Kuantitas pemberian umpan yang tidak seimbang dengan jumlah larva BSF akan mempengaruhi nilai WRI. Pengurangan sampah organik sebagai umpan larva BSF disajikan dalam bentuk tren persentase pada Gambar 6 .

Berdasarkan Gambar 6 dari perlakuan penelitian ini, sampah yang didapat dari pasar pada hari penelitian ke $3,4,5,6$, dan 7 telah membusuk, sehingga reduksi tertinggi terjadi pada jenis umpan sayuran. Reduksi pada umpan sayuran cenderung tinggi disebabkan sampah sayuran dari pasar yang diberikan telah membusuk (tidak dalam kondisi segar), sehingga memiliki tekstur yang lebih lunak. Nilai optimum dari setiap perlakuan terletak pada penelitian di hari ke 9 pengamatan. Pada hari ke 9 , terjadi reduksi tertinggi pada umpan sayuran dikukus, buah, dan buah difermentasi.

Setelah hari ke 9 pengamatan, terjadi penurunan signifikan dari ketiga jenis umpan yang diberikan. Hal ini disebabkan karena beberapa larva BSF telah melanjutkan ke fase berikutnya, yaitu prepupa. BSF pada fase ini cenderung mencari tempat yang kering dan tidak memakan umpan yang diberikan.
Berdasarkan hasil penurunan umpan larva, dapat disajikan nilai WRI dari setiap jenis umpan pada Tabel 2.

Berdasarkan Tabel 2, rata-rata nilai WRI tertinggi pada umpan jenis buah difermentasi mencapai $46,25 \%$, umpan jenis sayuran $42,29 \%$, umpan jenis sayuran dikukus $42,92 \%$, dan umpan buah hanya sebesar $33,75 \%$. Dalam penelitian ini, nilai WRI tertinggi $46,25 \%$ pada umpan buah yang difermentasi. Nilai ini lebih tinggi daripada penelitian terdahulu dengan feeding rate $100 \mathrm{mg} /$ larva/hari mendapatkan nilai WRI sebesar $0,42 \%$ dengan umpan larva yang diberikan berupa jerami padi yang telah terfermentasi(10). Nilai WRI mencapai $3,15 \%$ dengan umpan larva limbah buah(11). Nilai WRI mencapai $3,37 \%$ dengan umpan yang diberikan berupa jeroan dan kepala tuna(12). Nilai WRI mencapai $3,39 \%$ dengan umpan sayuran ${ }^{(4)}$. Nilai WRI mencapai $14,66 \%$ dengan umpan larva nasi(13). Dan nilai WRI mencapai 17,29 dengan umpan larva daun singkong ${ }^{(14)}$.

Buah difermentasi memiliki persentase nilai WRI tertinggi karena umpan yang diberikan telah dirombak terlebih dahulu oleh mikroorganisme lokal sehingga umpan buah difermentasi memiliki tekstur lunak. Selain itu bakteri fotosintetik dalam fermentasi mikroorganisme lokal akan mempercepat pembusukan dan menghasilkan asam amino 
yang dapat merombak serat dan sari makanan dalam umpan sehingga protein dapat dengan mudah diserap oleh larva BSF. Fungsi lain dari asam amino yaitu menghasilkan zat anti mikroba dari bakteri actinomiceter pada fermentasi sehingga meningkatkan palatabilitas dalam mengkonsumsi pakan yang telah diberikan.

Larva BSF mempunyai enzim selulolitik yang berfungsi melumatkan makanan dan mengeluarkan protein berada pada sari makanan. Enzim selulolitik akan dikeluarkan melalui mulut larva BSF, lalu makanan tersebut dihisap oleh larva BSF untuk dikonversikan dalam bentuk tubuhnya. Berdasarkan mekanisme makan larva BSF, umpan makanan sampah organik yang telah difermentasi menghasilkan asam amino, sehingga dapat memiliki percepatan reduksi yang tinggi. Berdasarkan Tabel 2 tingkat palatabilitas larva BSF dalam mengkonsumsi sampah organik menunjukkan sampah organik umpan yang lebih lunak memiliki tingkat reduksi yang tinggi.

\subsection{Efficiency of Conversion of Digested food}

Nilai Efficiency of Conversion of Digested food (ECD) menggambarkan tingkat efisiensi pakan yang dapat dicerna oleh larva BSF dan disimpan pada tubuhnya. Semakin tinggi nilai ECD maka semakin besar tingkat pakan yang telah dicerna oleh larva BSF. Pertumbuhan larva BSF dipengaruhi oleh 2 faktor, yaitu: faktor internal dan faktor eksternal. Faktor internal yaitu penyakit, parasit, dan jenis kelamin. Sementara faktor eksternal yaitu: ketersediaan umpan dan suhu pada media perkembangbiakan. Semasa hidupnya larva BSF hanya makan. Oleh karena itu, ketersediaan umpan harus tetap tersedia selama masa hidupnya. Media perkembangbiakan dapat menggunakan umpan dan residu dalam tempat perkembangbiakan. Nilai ECD dalam penelitian ini dapat dilihat pada Tabel 3.

Berdasarkan Tabel 3, rata-rata nilai ECD dalam penelitian ini bervariasi mulai $11-56 \%$. Nilai ECD terendah hanya $11 \%$ pada jenis umpan buah, sementara tertinggi mencapai $56 \%$ pada umpan jenis buah difermentasi. Tingkat kematian pada perhitungan akhir akan meningkatkan tingginya nilai ECD selain tingkat konsumsi umpan pada buah difermentasi. Dalam penelitian ini nilai ECD tertinggi $56 \%$ lebih tinggi daripada penelitian terdahulu dengan feeding rate $100 \mathrm{mg} / \mathrm{larva} / \mathrm{hari}$ yaitu dengan nilai ECD $3,03 \%$ dengan umpan jeroan tuna dan nilai ECD $7,6 \%$ dengan umpan kepala tuna(12). Sementara umpan jerami difermentasi mendapatkan nilai ECD $12,9 \%^{(10)}$. Dan umpan limbah buah mendapat nilai ECD mencapai $13,71 \%{ }^{(11)}$.

Perbedaan signifikan nilai ECD jenis umpan buah disebabkan oleh tingkat reduksi dan kematian larva dalam reaktor. Dalam umpan jenis buah difermentasi memiliki nilai ECD tinggi karena nilai reduksi tinggi dan tingkat kematian rendah, berbanding terbalik dengan umpan buah nilai reduksi rendah dan kematian rendah, sehingga pada perhitungan nilai ECD menghasilkan nilai rendah.

\subsection{Survival Rate}

Survival Rate (SR) menggambarkan tingkat keberhasilan hidup larva BSF selama hari yang ditentukan. Nilai SR akan mempengaruhi nilai ECD. Semakin besar nilai ECD maka tingkat keberhasilan hidup larva semakin tinggi(12). Namun hal tersebut tidak berlaku jika terdapat kematian larva pada masa pengamatan. Nilai survival rate dalam penelitian ini dapat dilihat pada Tabel 4.

Tabel 3. Nilai Efficiency of Conversion of Digested Food

\begin{tabular}{lcccc}
\hline \multicolumn{1}{c}{ Pengulangan } & Sayuran (\%) & Sayuran Dikukus (\%) & Buah (\%) & Buah Difermentasi (\%) \\
\hline Pengulangan 1 & 21 & 26 & 11 & 63 \\
\hline Pengulangan 2 & 28 & 26 & 11 & 50 \\
\hline Rata - Rata & 25 & 26 & 11 & 56 \\
\hline
\end{tabular}

Tabel 4. Survival Rate

\begin{tabular}{lcccc}
\hline Pengulangan & Sayuran (\%) & Sayuran Dikukus (\%) & Buah (\%) & Buah Difermentasi (\%) \\
\hline Pengulangan 1 & 77 & 78,5 & 85 & 81,37 \\
\hline Pengulangan 2 & 80 & 82,5 & 86,5 & 81,37 \\
\hline Rata - Rata & 78,5 & 80,5 & 85,75 & 81,37 \\
\hline
\end{tabular}


Berdasarkan Tabel 4, rata-rata nilai tingkat Survival Rate (SR) dalam penelitian ini sebesar $77-85,75 \%$. Rata-rata nilai tertinggi pada umpan jenis buah mencapai $85,75 \%$, sedangkan ratarata nilai terendah yaitu pada umpan jenis sayuran hanya $77 \%$. Penyebab kematian terbesar dalam penelitian ini disebabkan karena tidak adanya media, sehingga kelembaban dalam reaktor menjadi cukup tinggi. Dalam umpan jenis sayuran mempunyai nilai $S R$ terendah karena pemberian umpan sayuran busuk menghasilkan kadar air banyak sehingga terjadi kematian massal. Kadar air tinggi pada reaktor menyebabkan larva tidak makan umpan yang disediakan melainkan akan mencari tempat lebih kering.

Dalam penelitian ini media umpan yang digunakan bersifat basah sehingga menyebabkan terperangkapnya $\mathrm{NH}_{3}$ dan $\mathrm{CH}_{4}$ sehingga di dalam media perkembangbiakan menyebabkan panas dan larva kekurangan oksigen. Nilai SR tertinggi dalam penelitian ini mencapai $85,75 \%$ lebih tinggi daripada beberapa penelitian terdahulu dengan laju pemberian umpan $100 \mathrm{mg} / \mathrm{larva} / \mathrm{hari}$, yaitu: pada umpan kepala tuna mendapatkan nilai SR mencapai $80 \%$ dan umpan jeroan tuna nilai SR mencapai $40 \%{ }^{(12)}$. Sedangkan umpan daun singkong mendapatkan nilai SR mencapai $72,67 \%{ }^{(13)}$.

\section{KESIMPULAN}

Berdasarkan hasil penelitian, dapat disimpulkan, di antaranya: persentase reduksi atau waste reduction indeks dari umpan sayuran, sayuran dikukus, buah, dan buah difermentasi berturut-turut memiliki nilai rata-rata 42,29, $42,92 \%, \quad 33,75 \%$, dan $46,25 \%$. Sementara konversi pakan yang dapat dicerna atau Efficiency of Conversion of Digested food oleh larva BSF dari umpan sayuran, sayuran dikukus, buah, dan buah difermentasi berturut-turut memiliki nilai rata-rata $25 \%, 26 \%, 11 \%$, dan $56 \%$. Tingkat keberhasilan hidup atau Survival Rate dari umpan sayuran, sayuran dikukus, buah, dan buah difermentasi berturut-turut memiliki nilai rata-rata $78,5 \%, 80,5 \%, 85,75 \%$, dan $81,37 \%$.

\section{PERSANTUNAN}

Puji syukur kami panjatkan kehadirat Allah SWT atas rahmat dan karunia-Nya, sehingga tim penulis dapat menyelesaikan artikel ini. Untuk kesempatan ini tim penulis menyampaikan penghargaan setingi-tingginya ucapan terima kasih atas bapak Muhammad Rofi'i selaku pemilik CV. Karya Ladhuni Sejahtera yang telah memberikan bahan percobaan dalam penelitian ini.

\section{DAFTAR PUSTAKA}

1. Indartik, Suryandari, E. Y., Djaenudin, D., \& Pribadi, M. A. (2018). Penanganan Sampah Rumah Tangga di Kota Bandung: Nilai Tambah dan Potensi Ekonomi. Jurnal Penelitian Sosial dan Ekonomi Kehutanan, 15(3), 195-211. https://doi.org/10.20886/jpsek.2018.15.3.195211

2. Mintarsih, T. H. (2016). Kanal Komunikasi [Kementrian Lingkungan Hidup dan Kehutanan]. Rangkaian HLH 2015 - Dialog Penanganan Sampah Plastik. http://kanalkomunikasi.pskl.menlhk.go.id/rang kaian-hlh-2015-dialog-penanganan-sampahplastik/

3. Paramita, D., Murtilaksono, K., \& Manuwoto, M. (2018). Kajian Pengelolaan Sampah Berdasarkan Daya Dukung dan Kapasitas Tampung Prasarana Persampahan Kota Depok. Journal of Regional and Rural Development Planning, 2(2), 104. https://doi.org/10.29244/jp2wd.2018.2.2.104117

4. Nugraha, F. A. (2011). Analisis Laju Penguraian dan Hasil Kompos pada Pengolahan Sampah Sayur dengan Larva Black Soldier Fly (Hermetia Illucens). 1-11.

5. Suciati, R., \& Faruq, H. (2017). Efektivitas Media Pertumbuhan Maggots Hermetia illucens (Lalat Tentara Hitam) sebagai Solusi Pemanfaatan Sampah Organik. BIOSFER: Jurnal Biologi dan Pendidikan Biologi, 2(1), 813. https://doi.org/10.23969/biosfer.v2i1.356

6. Diener, S., Zurbrugg, C., \& Tockner, K. (2009) Conversion of organic material by black soldier fly larvae: Establishing optimal feeding rates. Waste Management \& Research, 27(6), 603-610. 10.1177/0734242X09103838

7. Scriber, J., \& Slansky, F. (1981). Selected bibliography and summary of quantitative food utilization by immature insects. Bulletin of the Entomological Society of America, 28(1), 4355.

8. Myers, H., Tomberlin, J., Lambert, B., \& Kattes, D. (2008). Development of black soldier fly (Diptera: Stratiomyidae) larvae fed dairy manure. Environmental Entomology, 37(1), 11-15.

9. Kim, W., Bae, S., Park, H., Park, K., Lee, S., Choi, Y., Han, S., \& Koh, Y. (2010). The Larva Lage and Mouth Morphology of the Black Soldier Fly, Hermetiaillucens (Diptera: Stratiomyidae). International Journal Industrial Entomology, 21(2), 185-187. 
10.Supriyatna, A, \& Putra, R. E. (2017). Estimasi Pertumbuhan Larva Lalat Black Soldier (Hermetia Illucens) Dan Penggunaan Pakan Jerami Padi Yang Difermentasi Dengan Jamur P. Chrysosporium. Jurnal Biodjati, 2(2), 159-166.

11. Nursaid, A. A., Yuriandala, Y., \& Maziya, F. B. (2019). Analisis Laju Penguraian dan Hasil Kompos pada Pengolahan Sampah Buah dengan Larva Black Soldier Fly (Hermetia Illucens). Universitas Islam Indonesia, 1-9.

12. Hakim, A. R., Prasetya, A., \& Petrus, H. T. B. M. (2017). Studi Laju Umpan pada Proses Biokonversi Limbah Pengolahan Tuna Menggunakan Larva Hermetia illucens. Jurnal
Pascapanen dan Bioteknologi Kelautan dan Perikanan, 12(2), 179-192. https://doi.org/10.15578/jpbkp.v12i2.469

13. Muhayyat, M. S., Yuliansyah, A. T., \& Prasetya, A. (2016). Pengaruh Jenis Limbah dan Rasio Umpan pada Biokonversi Limbah Domestik Menggunakan Larva Black Soldier Fly (Hermetia illucens). Jurnal Rekayasa Proses, 10(1), 23-29.

14. Darmawan, M., Prasetya, A., \& Sarto. (2017). I11-Budidaya Larva Black Soldier Fly (Hermetia illucens) dengan Pakan Limbah Dapur (Daun Singkong). SIMPOSIUM NASIONAL RAPI XVI, 6. 